\title{
Houkuttelevan asumisen ainekset
}

Jenni Kuoppa, Sini Saarimaa, Sampo Ruoppila, Markus Laine, Niina Nieminen, Risto Haverinen

Asukas- ja käyttäjälähtöinen suunnittelu vaatii tuekseen laajempaa ymmärrystä asumisen arjesta. Artikkelissa vastataan haasteeseen tarkastelemalla asukkaiden näkemyksiä asumisen koetuista laatutekijöistä. Tarkastelu perustuu tarjoumateoriaan, jota sovellettiin osallistavaa valokuvamenetelmää hyödyntävien fokusryhmähaastattelujen analyysissa. Tulokset nostavat esiin sellaisia houkuttelevan asumisen aineksia, joita on käsitelty toistaiseksi vain vähän tutkimuskirjallisuudessa. Tavoitteena oli rakentaa siltaa asukkaiden eletyn arjen ja tarjoumien todellisuudesta kohti suunnittelua. Asukaskokemusten perusteella on siis muotoiltu myös suunnittelussa hyödynnettäviä periaatteita.

Avainsanat: asumiskokemukset, käyttäjäkeskeinen asuntosuunnittelu, tarjoumat, osallistava valokuvamenetelmä, fokusryhmät

\section{Johdanto}

"Ikkunoista tuli luksusta ja minikopeista asuntoja", otsikoi Helsingin Sanomat pääkirjoituksensa 22.8.2020. Keskustelu suomalaisen asuntorakentamisen kokemuksellisesta laadusta on saanut uutta vauhtia nopean kaupungistumisen, asuntotuotannon kasvavien tehokkuusvaatimusten ja kaupunkilaisten yhä moninaisempien tarpeiden ristipaineessa. Suomalaista teollista asuntoraken- 
tamista onkin pitkään leimannut esteettinen yksitoikkoisuus sekä tarjolla olevien konseptien ja tilaratkaisujen yksipuolisuus (Gibler \& Tyvimaa, 2014; Juntto, 2008; Ilmonen, 2007). Tuotannon määrällisten tavoitteiden korostuessa asumisen viihtyisyys ja asukkaiden hyvinvointi näyttävät jääneen toissijaisiksi. Hyvä ympäristö ei kuitenkaan ole rahakysymys eikä hyvä, viihtyisyyttä lisäävä asuntoarkkitehtuuri saa olla harvojen etuoikeus. (Helander, 2020)

Asukkaat ovat asumisen tarpeiden ja kokemuksellisen laadun parhaita asiantuntijoita. Ideaalitilanteessa suunnittelijat voisivat aloittaa jokaisen hankkeen keräämällä tietoa asuntojen tulevilta käyttäjiltä (vrt. Maier \& Fadel, 20og, s. 405-406). Käytännössä näin ei juurikaan tapahdu, ainakaan tiukasti tulosohjatussa asuntorakentamisen mallissa. Silloinkin tietoa tarjoaa asukaslähtöinen tutkimus.

Ymmärrys siitä, mistä aineksista hyväksi koettu asuintila ja asunnon välitön elinympäristö koostuvat, on kuitenkin melko kapeaa. Asumispreferenssien tutkimus on perustunut kyselyihin ja karkeisiin kategorisointeihin, jotka ovat lähinnä uusintaneet yksiulotteisia ja puutteellisia käsityksiä asumisen ihanteista (Lapintie, 2010). Asukkaiden arvostuksia kuvaava tieto on nähty myös liian yleistasoisena asuntosuunnittelun tarpeisiin. Siinä missä asuntojen sijaintiin, asuntotyyppiin ja hallintamuotoon liittyviä preferenssejä on tutkittu paljon, on asukkaiden näkökulma pienipiirteisiin asumisen laatutekijöihin ja asuinrakennusten sisätiloihin jäänyt vähemmälle huomiolle (Pirinen, 2014, s. 28).

Asuntoarkkitehtuurin laadullisia ominaisuuksia on eritellyt esimerkiksi Nylander (2002), mutta asukkaiden kokemusten näkökulma on jäänyt puutteelliseksi. Kiinnostavia viimeaikaisia poikkeuksia ovat kuitenkin olleet esimerkiksi Tervon ja Liliuksen (2017) sekä Tervon ja Hirvosen (2019) urbaanien yksinasujien asuintilatoiveita koskevat tutkimukset, Huttusen ym. (2015) townhouse-asumista koskeva tutkimus sekä Hasun (2014; 2017) asuntojen ulkotiloihin laajenemista koskevat tarkastelut sekä asumisen valintoja ja päätöksentekoa avaava tutkimus. Pirisen (2014) tutkimuksessa asuntoa tarkasteltiin tuotteena teollisen tuotannon, käyttäjien ja muotoilun näkökulmista. Siinä asukkaat kuvaavat asuntojaan arvokkaiden ominaisuuksien yhdistelminä, mutta Pirisen johtopäätökset kohdistuvat asuntojärjestelmään ja käyttäjäkeskeisen teollisen asuntotuotannon kehittämiseen laajemmin.

Tutkimuksemme metodologinen lähtökohta oli suunnitella empiirinen asetelma niin, että asukkailla oli tilaisuus määritellä asumisen viihtyisyyttä ja houkuttelevuutta lisääviä tekijöitä mahdollisimman vapaasti. Tavoitteena oli tuottaa ymmärrystä siitä, millaiset tarjoumat asuntojen sisätiloissa, asuinrakennuksessa ja välittömässä asuinympäristössä lisäävät koettua viihtyisyyttä ja houkuttelevuutta. Tutkimuskysymyksemme on: mitkä tai minkälaiset tarjoumat tekevät asumisen tiloista viihtyisiä ja houkuttelevia? Kysymykseen 
vastaamisen lisäksi pyrimme ylittämään asumistutkimuksessa tunnistetun katkoksen asukastiedon ja asuntosuunnittelun välillä (esim. Pirinen, 2014, s. 210; Maier, Fadel \& Battisto, 20og). Siksi olemme muodostaneet tuloksista myös asuntosuunnittelussa hyödynnettäviä periaatteita.

\section{Tarjouman käsite metodologisena haasteena}

Asukkaat osallistuvat asunnon ja kodin tuottamiseen yhtä lailla kuin arkkitehdit ja rakennuttajat. Tämä tapahtuu asumisen prosessissa (inhabitation), kun asukkaat tekevät asunnon kodikseen, eletyksi tilaksi (Nethercote \& Horne, 2016; acobs \& Merriman, 2011). Topografian eli geometrisen ja mitattavan tilan rinnalle asettuu topologia, tilojen kokeminen ja eläminen - laadulliset ominaisuudet, jotka eivät välttämättä ole mitattavia tai edes suunniteltavia (Nethercote \& Horne, 2016). Tilan topografiset ja topologiset olomuodot ovat keskenään vuorovaikutteisessa, jännitteisessä suhteessa. Tarvitaan käsitteitä, jotka auttavat ylittämään dualismeja mitattavan ja koetun, fyysisen ja sosiaalisen, objektiivisen ja subjektiivisen välillä. Yksi tällainen käsite on tarjouma.

Tarjouman käsite on peräisin James Gibsonin (1979) kehittämästä ekologisesta psykologiasta ja se viittaa niihin toiminnan ja kokemisen mahdollisuuksiin, joita yksilö havaitsee fyysisessä ympäristössään, käsillä olevan toiminnan kontekstissa (Gibson, 1979, s. 127). Tarjouman käsitteen kautta tarkastelun kohteena on siis ympäristön juuri tietylle asukkaalle mahdollistama toiminta ja siihen liittyvät merkitykset (clapham, 2011). Se ohjaa tarkastelemaan asumisen konkreettisia, paikkasidonnaisia kokemuksia ja toimintoja esimerkiksi abstraktimpien arvojen tai toiveiden sijaan (Heft \& Kyttä, 2006, s. 212). Tarjoumat ovat jatkuvasti tapahtuvia, tilannekohtaisia ja yksilöllisiä vuorovaikutuksia ympäristön kanssa. Yksittäinen tilan fyysinen ominaisuus voi liittyä siis eri toimintoihin eri käyttäjillä. Tarjoumat kuitenkin myös vakiintuvat ja rutinoituvat osaksi arkisia paikkoja. Käsitteen avulla asumisen merkitykset, toiminnot ja käytännöt voidaan näin kytkeä asuinympäristön fyysisiin ja tilallisiin ominaisuuksiin. (Clapham, 201; Heft \& Kyttä, 2006; Kuoppa, Nieminen, Ruoppila \& Laine, 2019)

Käsitettä on pidetty lupaavana asumisen ja muun rakennetun ympäristön tutkimuksessa (Clapham, 2011; Coolen, 2015; Coolen \& Meesters, 2012a, 2012b; Heft \& Kyttä, 2006; Lapintie, 2010), mutta sitä on sovellettu alan empiirisessä tutkimuksessa suhteellisen vähän (Kyttä ym., 2013, s. 32; Maier ym., 20og). Käsitteen hyödyntämisen keskeisiä ongelmia ovat olleet yhtäältä, miten asukkaat saisivat mahdollisimman vapaasti määritellä heille merkitykselliset tarjoumat, ja toisaalta, miten asumisen fyysinen ja tilallinen ulottuvuus sekä merkitykset ja käytännöt kytketään menetelmällisesti yhteen (Kuoppa ym, 2019). 
Ideaalitapauksessa tutkijan ei siis pidä etukäteen olettaa ja määrittää asunnon tai asuinympäristön fyysisten ja tilallisten elementtien, niiden käyttötapojen ja merkityksien välistä suhdetta (vrt. Coolen, 2015), vaan tarjoumasuhteita tulisi selvittää empiirisesti ja kontekstisidonnaisesti. Suomessa esimerkiksi Marketta Kyttä tutkimusryhmineen on kehittänyt tähän soveltuvia karttapohjaisia kyselyitä, jotka ovat tuottaneet paikkasidonnaista käyttäjätietoa kaupunkisuunnitteluun (mm. Broberg ym., 2013; Kyttä ym., 2013, 2018), mutta myös pienipiirteinen asumisen mittakaava on kaivannut menetelmällisiä avauksia. Haasteena on myös löytää tapoja kurkistaa sisään asukkaiden yksityisiin tiloihin, aivan kirjaimellisesti, jotta tavoitetaan asumisen arki, asunnon käyttötavat ja niiden merkityksellisyys (King, 2017, s.1-2). Tämän mahdollistamiseksi hyödynsimme tutkimuksessa osallistavaa valokuvamenetelmää.

\section{Menetelmät ja aineisto}

Artikkeli perustuu ReCiDi-tutkimusprojektissa (2016-2017) kerättyyn aineistoon. Aineiston tarkastelua suunnittelunäkökulmasta on jatkettu Miksi Turkuun? -hankkeessa (2019-2020). ReCiDi-tutkimus toteutettiin Turussa ja Tampereella, joissa kerättiin aineistoa osallistavaa valokuvamenetelmää soveltavilla fokusryhmähaastatteluilla syksyllä 2016. Osallistujia pyydettiin ottamaan ennen fokusryhmää neljä valokuvaa: ensinnäkin heitä eniten miellyttävistä puolista sekä nykyisessä asunnossa että asuinympäristössä, ja toiseksi asumisen huonoista puolista sekä asunnossa että asuinympäristössä. Ohjeistus pidettiin tarkoituksella väljänä. Osallistujat ottivat valokuvat omilla kännykkäkameroillaan ja lähettivät kuvat etukäteen tutkijoille. Ryhmien keskustelut jäsentyivät näiden väljien teemojen ja valokuvien ympärille, ja osallistujilla oli siten merkittävä rooli tarkempien teemojen esiin nostajina. Lisäksi tutkijat esittivät tarkentavia kysymyksiä. Tässä artikkelissa keskitytään asuntoja ja asuinkorttelia koskeviin tuloksiin.

Valokuva-avusteisen haastattelun (photo-elicitation) idea on saada aikaan sisällöllisesti rikkaampaa ja laadullisesti uudenlaista keskustelua verrattuna perinteiseen haastattelutilanteeseen (Harper, 2002, s. 13). Menetelmää on käytetty melko laajalti ihmistieteiden aloilla ja tutkimuksissa on hyödynnetty sekä tutkijoiden että tutkimuksen osallistujien ottamia kuvia. Asumistutkimuksessa osallistujien valokuvien käyttö on ollut melko harvinaista (soaita \& McKee, 2020). Tyypillisesti osallistavaa valokuvamenetelmää on hyödynnetty erityisesti marginaalisten, heikommassa asemassa olevien tai "vaikeasti tavoitettavien" ryhmien elämän ja kokemusten ymmärtämisen apuna, esimerkiksi tutkimuksissa kodittomien naisten käsityksistä kodista ja kodittomuudesta (McCarthy, 2018), pakolaisten tavoista rakentaa kotia (Fozdar \& Hartley, 2014) ja asuinpaikan vaikutuksista pienituloisten 
ikääntyneiden käsityksiin itsenäisyydestä ja terveydestä (Kohon \& Carder, 2014). Soaita ja McKee (2020) sovelsivat osallistujien valokuvia puhelinhaastatteluissa yksityisen sektorin vuokralaisten kanssa Britanniassa tutkiakseen heidän tapojaan personoida kotia. Suomessa Pirinen (2014) hyödynsi tutkimuksessaan valokuvia luotaamaan asukkaiden jokapäiväisiä asunnon käyttökokemuksia.

Valokuvien käytöllä pyrittiin vastaamaan tarjoumia koskevan tutkimuksen keskeisiin metodologisiin haasteisiin: yhtäältä vältettiin määrittämästä mahdollisia tarjoumia ennalta ja toisaalta kytkettiin tutkimus todellisiin, erilaisten paikkojen ja asuntojen konteksteihin. Menetelmällä asukas sai määritellä ne asiat, jotka hänen näkökulmastaan nousevat merkittäviksi hyvän - tai huonon - asumisen tekijöiksi. Valokuva-avusteinen haastattelu auttoi tuomaan esiin asumisen arjen konkreettisia puolia: asumisen tarjoumien fyysiset ja tilalliset elementit sekä käytäntöjen ruumiillisen, aistimellisen ja tilallisen ulottuvuuden. Valokuvat myös auttoivat keskustelemaan sellaisista asumisen rutiininomaisista kokemuksista, jotka jäävät tavanomaisessa haastattelussa helposti piiloon - juuri koska ovat asukkaille niin arkisia ja lähes itsestään selviä. (Kuoppa ym., 2019; Soaita \& McKee, 2020.) Kun asukkaiden tuottama kokemustieto liitettiin metodologisesti fyysiseen ympäristöön ja tilaan, luotiin mahdollisuus kytkeä se tuleviin suunnitteluratkaisuihin (vrt. Kahila \& Kyttä, 2017, s. 138).

Fokusryhmät muodostettiin elämänvaiheperustaisesti. Kummassakin kaupungissa toteutettiin neljä ryhmää: lapsiperheiden vanhempien, pariskuntien ja sinkkujen, ikääntyneiden (65+) sekä opiskelijoiden (AMK tai yliopisto) ryhmät. Kussakin ryhmässä oli 5-7 osallistujaa, paitsi Turun opiskelijoiden ryhmässä vain neljä. Pariskuntien ja sinkkujen ryhmiin osallistuivat ne, joilla ei ollut kotona asuvia lapsia. Mukana oli myös osallistuja, jonka lapsi oli juuri muuttamassa pois kotoa. Ikääntyneiden ryhmät koostuivat itsenäisesti asuvista, hyväkuntoisista eläkeläisistä. Kaikki tutkimuksesta kiinnostuneet otettiin mukaan keskusteluihin ja heille löytyi näillä määritelmillä sopiva ryhmä. Yhteensä tutkimukseen osallistui 48 asukasta, joista enemmistö oli naisia (33). Keskusteluissa ei kuitenkaan tullut ilmi sellaisia seikkoja, joissa asumisen kokemukset olisivat eriytyneet nimenomaan sukupuolen mukaan.

Kaikki Tampereen osallistujat (25) asuivat Tesoman kaupunginosassa tai sitä ympäröivillä asuinalueilla enintään noin kolmen kilometrin säteellä Tesoman keskuksesta. Tesoma on 1960-1970-luvun metsälähiö, jota täydennysrakennetaan ja kehitetään voimakkaasti. Turussa osallistujia haettiin avoimilla ilmoituksilla, joissa mukaan kutsuttiin uudenaikaisissa puukerrostaloissa asumisesta sekä Linnanfältin puukaupungin rakentamisesta kiinnostuneita. Linnanfältti on Turun keskustan ja linnan kupeeseen, vanhaan teolliseen ympäristöön ja puutalovyöhykkeen jatkeeksi suunniteltu uusi asuinalue. Useimmat 
osallistujista (23) asuivat Turun kantakaupungissa ja sitä ympäröivällä puutalovyöhykkeellä, mutta jotkut myös kauempana sijaitsevilla alueilla. Vaikka fokusryhmät muodostettiin elämänvaiheisiin perustuen, Turussa tapa kerätä osallistujia tuotti aineistoon myös elämäntyyliulottuvuuden: puutaloasuminen leimasi selkeästi joidenkin osallistujien arvostuksia. Tampereella kiinnostuneita koottiin suorilla yhteydenotoilla ja alueelle suuntautuneilla käynneillä. Kaikki tesomalaiset eivät edusta kerrostaloasujia tai metsälähiölle tyypillisen korttelin asukkaita, eivätkä kaikki Turun osallistujat edusta kaupunkimaista asumista. Kaksi tutkimuskontekstia tarjosi vaihtelua ja moninaisuutta osallistujien asumisolosuhteiden ja -kokemusten suhteen. Kontekstuaalisesti he toivat tarkasteluun mukanaan laajasti eri asuntotyyppejä, korttelirakenteita, hallintamuotoja ja erilaisia kaupunginosia. Tämä moninaisuus lisää tulosten yleistettävyyttä.

Tutkimuksen aineisto koostuu yhteensä kahdeksasta nauhoitetusta ja litteroidusta fokusryhmäkeskustelusta, joista kukin kesti noin kaksi tuntia, sekä lisäksi noin 150 valokuvasta. Analyysissa olennaista oli se, miten osallistujat kuvasivat taustoja ja syitä tietyn asian valokuvaamiselle ja millaista keskustelua kuvat ryhmässä herättivät. Sisällönanalyysi eteni aineistolähtöisesti, eli yksittäisistä havainnoista ja asukkaiden kokemusten moninaisuudesta edettiin yleisempiin kategorioihin. Tuloksissa esitetyt tarjoumien kategoriat toistuivat läpi aineiston ja saivat erilaisia ilmenemiä eri keskusteluissa ja yksilöiden kokemuksissa. Elämänvaiheisiin liittyviä eroja asukkaiden kokemuksissa eritellään tuloksissa silloin, kun niitä on noussut aineistossa esiin.

Käsitteellinen kehys ohjasi analyysia siten, että asukkaille tärkeitä asunnon ominaisuuksia kuvaavaa haastattelupuhetta koodattiin tarjoumiksi kiinnittäen erityistä huomiota siihen, että tarjoumat voivat olla joko kokemuksellisia tai toiminnallisia (useimmiten kumpaakin) ja lisäksi ne ovat aina materiaalisia ja merkityksellisiä. Tarjoumien tilallisen ja materiaalisen ulottuvuuden analyysia auttoi terävöittämään valokuvien yksinkertainen luokittelu sen mukaan, millaisia tiloja ja fyysisiä asumisen elementtejä ne esittivät.

Koska mallit siihen, kuinka tutkimuksessa osallistujalähtöisesti tunnistetuista tarjoumista tai niiden kategorioista johdetaan asuntosuunnittelun periaatteita pitkälti puuttuvat, hahmotimme kokeilevalla otteella siirtymää houkuttelevan asumisen aineksista kohti suunnittelun periaatteita ja tavoitteita. Kuten tarjoumakategoriat, myös asuntosuunnitteluun sovellettavat periaatteet ovat riittävän yleisiä ja abstrakteja sovellettavaksi monenlaisiin fyysisiin ympäristöihin, asuntotyyppeihin ja hallintamuotoihin. 


\section{Houkuttelevan asumisen ainekset}

Osallistavaa valokuvamenetelmää soveltavat fokusryhmähaastattelut toivat esiin sellaisia asumisen laatutekijöitä, joita on toistaiseksi käsitelty asukkaiden arvostuksia käsittelevässä tutkimuksessa niukasti. Ne myös haastavat yksinkertaisia asunnon ja asuinympäristön välisiä jakolinjoja.

\section{Hyvät toissijaiset tilat}

Osallistujat kuvailivat paljon arjen päivittäisiin käytäntöihin liittyviä tiloja ja järjestelyjä, jotka aiheuttavat vaikeuksia arjessa. Usein ongelmat liittyivät huonosti toimiviin tai liian pieniin eteisiin, portaikkoihin, säilytys- ja varastotiloihin tai kodinhoitotiloihin. Lisäksi iäkkäämmät osallistujat puhuivat hissien puuttumisesta, liian raskaista ovista tai muista esteettömään liikkumiseen liittyvistä ongelmista. Fokusryhmäkeskusteluista nousseet tulokset korostivat siis sellaisten tilojen tärkeyttä, joita käytetään jatkuvasti osana arkea, mutta joita pidetään usein toissijaisina ja joita ei ole asukkaiden näkökulmaa avaavissa tutkimuksissa tarkemmin juurikaan tarkasteltu.

Eteistilat ovat asunnon toiminnallisuuden kannalta tärkeitä solmukohtia. Niiden ahtaus, huonot säilytystilat, sopimattomat lattiamateriaalit tai tuulikaapin tai kuraeteisen puute koettiin arkea hankaloittavina tekijöinä. Eteisistä lika kulkeutuu helposti muualle asuntoon ja ulkovaatteiden ja kenkien säilytys tuottavat päänvaivaa. Myös perheen uloslähtö pukemisineen saattaa olla vaivalloinen tapahtuma. Fokusryhmään Tesomalla osallistunut asukas esittelee valokuvaansa (kuva 1):

Joo, siis mä en mitenkään siivonnu tätä. Tää on aina yleensä tän näkönen et ihan otin kuvan näkee kaikki tavarat vaan pursuaa tuolta molemmista reunoilta tohon keskelle. Ja tää valaistus on aivan kammottavaa (...) Mut siinä ei oikeen nää mitään ja sit -- siin ei kaks ihmistä mahdu toimiin mitenkään. Ku sä laitat kenkiä jalkaan ja pyllistät niin et mahdu ohi vaikka vatsaa vetäis sisään. Et se on ihan katastrofi lasten kans -- meil on opittu et no niin mene sinä laittaan kengät jalkaan. Sit kävele siihen ovelle oottaan, meet sinä laittaan kengät jalkaan ja kävele ovelle ja -- et ihme tällanen marssijärjestys et jotenki tykkäisin semmosesta kun on niitäkin asuntoja joissa on -- neliön mallinen iso eteinen et siinä mahtuu kaikki toimiin yhtä aikaa.

Tilat, jotka mahdollistavat tavaroiden ja asioiden organisoinnin, järjestämisen ja säilyttämisen olivat myös merkityksellisiä osallistujille. Ne näyttäytyivät usein puutteellisina. Näiden tilojen merkitys kytkeytyi myös usein jollain tavalla 


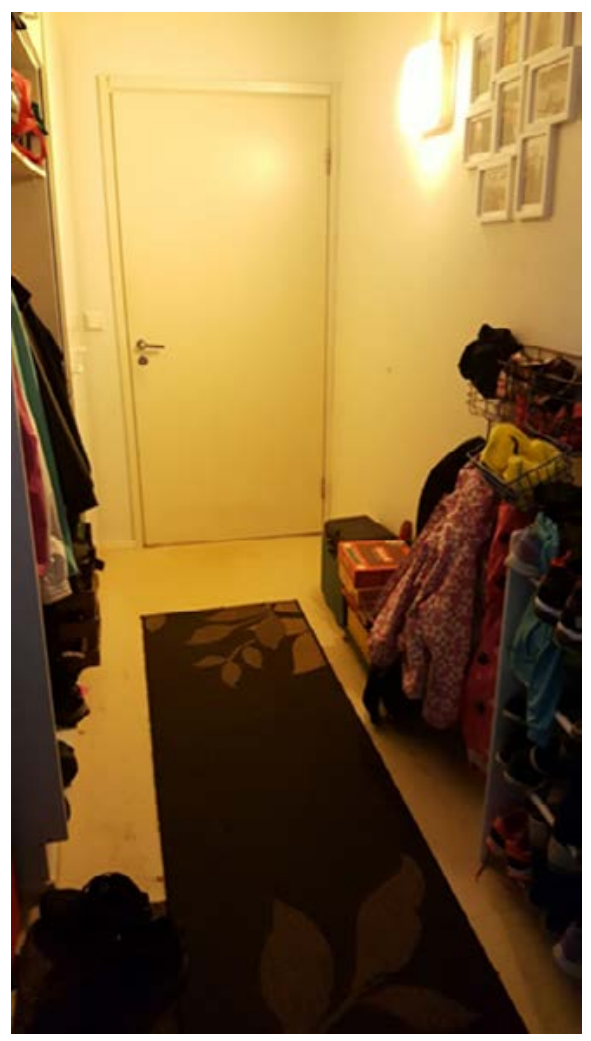

KUVA 1:

Osallistujan kuvaama toimimaton eteistila

elämänvaiheisiin: opiskelija kaipasi kiinteää säilytystilaa, koska asuinpaikan vaihtuessa suhteellisen tiheään irrallisten säilytyskalusteiden muuttaminen ei houkutellut. Uusperheessä tavaroiden säilyttäminen, järjestäminen ja kuljettelu liittyivät liikkumiseen kotien välillä ja tilan haltuunottoon. Lasten muuttaessa pois kotoa taas pohdittiin säilytyskysymyksiä uudelleen. Näin tarjoumat kietovat yhteen sosiaalisia ja elämänvaiheisiin liittyviä merkityksiä, arkisia toimintoja ja fyysisiä tiloja. Säilytystilan merkityksen ovat tunnistaneet ainakin Juntto ym. (2010), Pirinen (2014, s. 234) sekä Gibler ja Tyvimaa (2014, s. 375), mutta tarkastelut ovat jääneet vähäiseksi verrattuna kodin ensisijaisiin toimintoihin ja päätiloihin (olohuoneet, keittiöt ja makuuhuoneet) (ks. kuitenkin Steele \& Keys, 2015).

Varastoinnin, säilyttämisen, siivoamisen, pyykinpesun tai tilasta toiseen kulkemisen kuuluu useimmiten olla sellaista arkipäiväistä toimintaa, joka jää kotiin liittyvien merkitysten maisemassa taka-alalle ja näkymättömiin. Kuitenkin silloin, kun asumisen fyysiset tilat eivät vastaakaan näihin toimintoihin liittyviin tarpeisiin - kun tarjoumasuhde asukkaan ja asunnon välillä kääntyy kitkaiseksi - niiden merkitys arjessa nousee esiin. Samalla sellaiset asumisen 
tilat, joita on totuttu ajattelemaan toissijaisina tai kodin "aputiloina" suhteessa ensisijaisiin oleskelun tiloihin, näyttäytyvät tärkeinä.

\section{Toissijaiset tilat suunnittelun näkökulmasta}

Eri asuintilojen ja -toimintojen välillä liikkumisen mahdollistavien tilojen (eteinen, käytävät) sekä tilojen, joissa organisoidaan, järjestetään ja säilytetään tavaroita ja asioita (esim. vaatehuone) kehittämistä voi suunnittelun näkökulmasta lähestyä sekä fyysisen käytettävyyden että tilan kokemuksellisuuden paremmalla huomioimisella.

Vaikka toissijaiset tilat on tunnistettu suunnitteluohjeistuksissa (RT 93-10945, 2009: RT 93-10937, 2008), tutkimuksemme valossa näyttää siltä, ettei näiden tilojen merkitystä ole tarkasteltu tarpeeksi asukkaiden erilaisten tarpeiden näkökulmasta. Esimerkiksi se, miten toissijaisia tiloja voidaan kehittää palvelemaan tuloksissa kuvattuja vaihtelevia ja muuttuvia asumisen tilanteita eri elämänvaiheissa, on jäänyt vähemmälle huomiolle. Suunnittelun näkökulmasta tutkimuksemme korostaakin myös asukkaiden mahdollisuutta käyttää toissijaisia tiloja eri tavoin tai muokata niistä omanlaisensa. Tietynlaiset tilan muodot ja ulottuvuudet antavat muita paremmat lähtökohdat tälle. Kuten edellä kuvattiin, eteistilassa on läpikulun lisäksi lähes aina tarve säilyttää suuri määrä tavaraa, mitä lisää Suomessa vielä vuodenaikojen ja säiden vaihtelu. Tuloksissa korostui myös, että usean käyttäjän on monesti pystyttävä käyttämään eteistilaa samanaikaisesti eri toimintoihin. Eteistilan käytännöllisyyttä parantavat laajuus (johon suomalaiset esteettömyysvaatimukset jo osin johtavat) sekä pitkät ehjät seinäpinnat, joita voidaan hyödyntää säilytykseen tai muihin tarpeisiin tehokkaasti. Kaappien lomaan voidaan myös sijoittaa syvennys, jolloin saadaan lisätilaa esimerkiksi liikunta-apuvälineelle. Eteistilan ei tarvitse olla suurempi kuin esteettömyysmääräykset vaativat, mutta tilojen koon maltillinen lisääminen mahdollistaa usein niiden mukauttamisen vaihteleviin käyttöihin.

Huomioimalla eteisen tai vaatehuoneen avautumisen suunta sekä toissijaisten tilojen ja asuinhuoneiden ikkuna-aukotuksen yhteys, voidaan keinovalaistusta täydentää luonnonvalolla ja näkymillä. Asuntojen toissijaisten tilojen kehittäminen onkin sidoksissa urbaanien talotyyppien ja niiden luonnonvaloominaisuuksien kehittämiseen. Esimerkiksi uudiskerrostalojen runkosyvyyksiä kaventamalla ja niiden porrashuoneratkaisuja muokkaamalla voidaan paitsi välttää eteisten sijoittaminen nurkkaan, mikä aiheuttaa usein käytävä- ja hukkatiloja, myös parantaa asuntojen luonnonvalo-ominaisuuksia (saarimaa \& Pelsmakers, 2020). Valoisa tila vaikuttaa myös kokoaan suuremmalta (esim. Stamps, 2010). 


\section{Aistikokemukset määrittävät asumisviihtyvyyttä}

Asumiseen liittyvät moniaistiset kokemukset näyttäytyvät tuloksissamme koetun laadun tärkeänä osatekijänä. Epämiellyttävät aistikokemukset, jotka olivat usein seurausta talon puutteellisista teknisistä ratkaisuista (ilmastointi, lämmitys, akustiikka, äänieristys), heikensivät monen osallistujan asumisviihtyvyyttä. Asumisen tarjoumasuhteissa hajuja, ääniä ja lämmönvaihteluja ei voi sulkea pois kokemuksista. Niiden syyt saattavat olla sellaisia, joihin asukkaat eivät voi itse vaikuttaa, mikä tekee niistä ehkä erityisen häiritseviä. Esimerkiksi siihen, että asunto on rakenteellisten syiden vuoksi pimeä, on asukkaan hankala vaikuttaa mitenkään.

\section{Paistaaks sulla aurinko ollenkaan tonne?}

No se on siis toinen ongelma -- kun toi on -- upotettu parveke, eli olohuoneen ikkuna on siellä -- parvekkeen takana, niin sinne muutenkin tulis vähemmän valoa ja sit ku toi talo on vielä siinä edessä niin meidän olkkariin paistaa aurinko 15 minuuttia päivässä ja se on siinä, ja olkkari on se joka on etelään päin, eli toisella puolella taloo on ehkä vartin aamulla, vartin illalla valoa, ei talvella mut ... (...) et -- se unelma-asunto sit joskus on semmonen joka kylpee valossa, mun mielestä se on ihana se vartti, mut se on tosiaan niin lyhyt

Toisaalta tarjoumat ovat olennaisesti sosiaalisia ja kulttuurisia. Esimerkiksi Turun puutaloasukkaiden kuvauksissa kylmyyden kokemus nähtiin puutaloasumiseen liittyvänä eräänlaisena välttämättömänä pahana.

Asuntojen miellyttävimpiä seikkoja koskevat kuvat ja kuvaukset puolestaan liittyivät hyvin usein valoisuuteen, tilan tuntuun sekä ikkunanäkymiin. Asukkaiden keskusteluissa tärkeät ikkunanäkymät sijaitsivat useimmiten olohuoneessa tai ruokailutilassa sekä keittiössä. Miellyttäviksi koettiin vaihdellen pihanäkymät, luontoelementit kuten puut tai puiden latvat, metsä tai vesi sekä myös tila tai avaruus ja miellyttävä rakennettu ympäristö. Paikat, joissa mieluiten vietettiin aikaa, sijaitsivat asunnossa usein niissä kohdissa, joissa ulkotila oli läsnä ikkunanäkymän välityksellä ja luonnonvalo virtasi sisään.

Valoisuuden merkitys miellyttävän tunnelman luojana tuntui korostuvan pienissä asunnoissa, joissa valo tuo myös avaruuden tunnetta. Turussa kaksiota asuttava nelihenkinen perhe oli vaihtamassa asuntoa lähitulevaisuudessa suurempaan, mutta huolimatta tilanteesta, jossa vanhemmat nukkuivat olohuoneessa ja lapset ainoassa makuuhuoneessa, perheen äiti koki tilan viihtyisänä. Tässä esimerkissä haastateltavan asumiskokemusta määrittää kaksi perustarvetta, valo ja tila, jotka kompensoivat toisiaan kiinnostavalla 
tavalla. Valoisuuden ja tilavuuden tarjoumat kytkeytyvät esimerkissä yhteen ja syntyvät monien materiaalisten ja fyysisten elementtien, kuten asunnon pohjan ja koon, ikkunoiden koon ja suunnan, avarien tai esteettömien näkymien ja asuinkerroksen yhteisvaikutuksessa. Samankaltaisia havaintoja on mahdollista tehdä läpi aineiston: tarjoumat syntyvät asukkaille eri tekijöiden vuorovaikutuksissa ja niitä on vaikea pelkistää johonkin tiettyyn fyysiseen objektiin. Osallistuja esittelee valokuvaansa (kuva 2):

Joo eli tää kuva on tilanne et on iso olkkari mis on sit jaettu vähän olohuonepuolta ja sitten tää meiän sänky. Ja hyvä asia täs nyt oli, -- se et se on valoisa, ja tosiaan kun tuol on ikkunat kahdesta suunnasta ja -- [asuminen] sit jatkuu viel keittiöön et se on -- avattu neliön muotoseks se koko plaani. Sit siellä on viel -- koko huoneiston levynen parveke niin se valo on ehdottomasti tärkeetä et, suhteellisesti suurempi olohuone moneen kerrostaloasuntoon verrattuna niin silti siin on ympätty tavallaan, kaks huonet yhteensä niin se valo on semmonen joka sitten, avartaa sitä tilaa selvästi kyllä.

Se miltä asuminen tuntuu, kuulostaa, tuoksuu tai jopa maistuu, on asukkaille tärkeää. Osallistujat esittelivät kuvia esimerkiksi erilaisista takoista ja tulipesistä, jotka tuottivat asumiseen tietynlaista tunnelmaa erityisesti vanhoissa puutaloissa. Asunnon ulkotiloja arvostettiin myös niiden tarjoamien aistikokemusten vuoksi, kuten alla olevassa sitaatissa, jossa osallistuja kuvaa puutarhansa tarjoumia, jotka ovat olennaisesti aistimellisia ja ruumiillisia.

Se (kuva) kertoo mun pihastani -- Toi omenamehupuristin on sen tähden et siit tulee -- hajua ja makua teille kun te näätte sen, [naurahtaa] tuoremehun. Ja mun mielestäni piha on, paitsi että se on tällanen, luomua ilmaisruokaa, se on myös mul on lähtökohta että se on kaunis, ja sitä voi syödä. Ja että siellä viihtyy. Ja tosissaan siel viihtyy ystävät ja minä, elikkä se on semmonen, justiin kesäajan olohuone

\section{Aistikokemukset suunnittelun näkökulmasta}

Aistien näkökulmasta miellyttävät asumisen suunnitteluratkaisut ovat olleet viime aikoina kasvavan kiinnostuksen kohteena. Aihetta on lähestytty erityisesti luonnonelementtejä korostavan suunnittelun (ks. mm. Kellert, 2005; Kellert \& Calabrese, 2015) ja kokonaisvaltaisen esteettömyyden näkökulmasta (ks. mm. Jokiniemi, 2007; Hannukainen ym., 2019). Ensimmäisestä on käytetty biofiilisen suunnittelun ja jälkimmäisestä esimerkiksi aistiesteettömyyden termejä. Erityisesti luonnonvalon merkitystä 


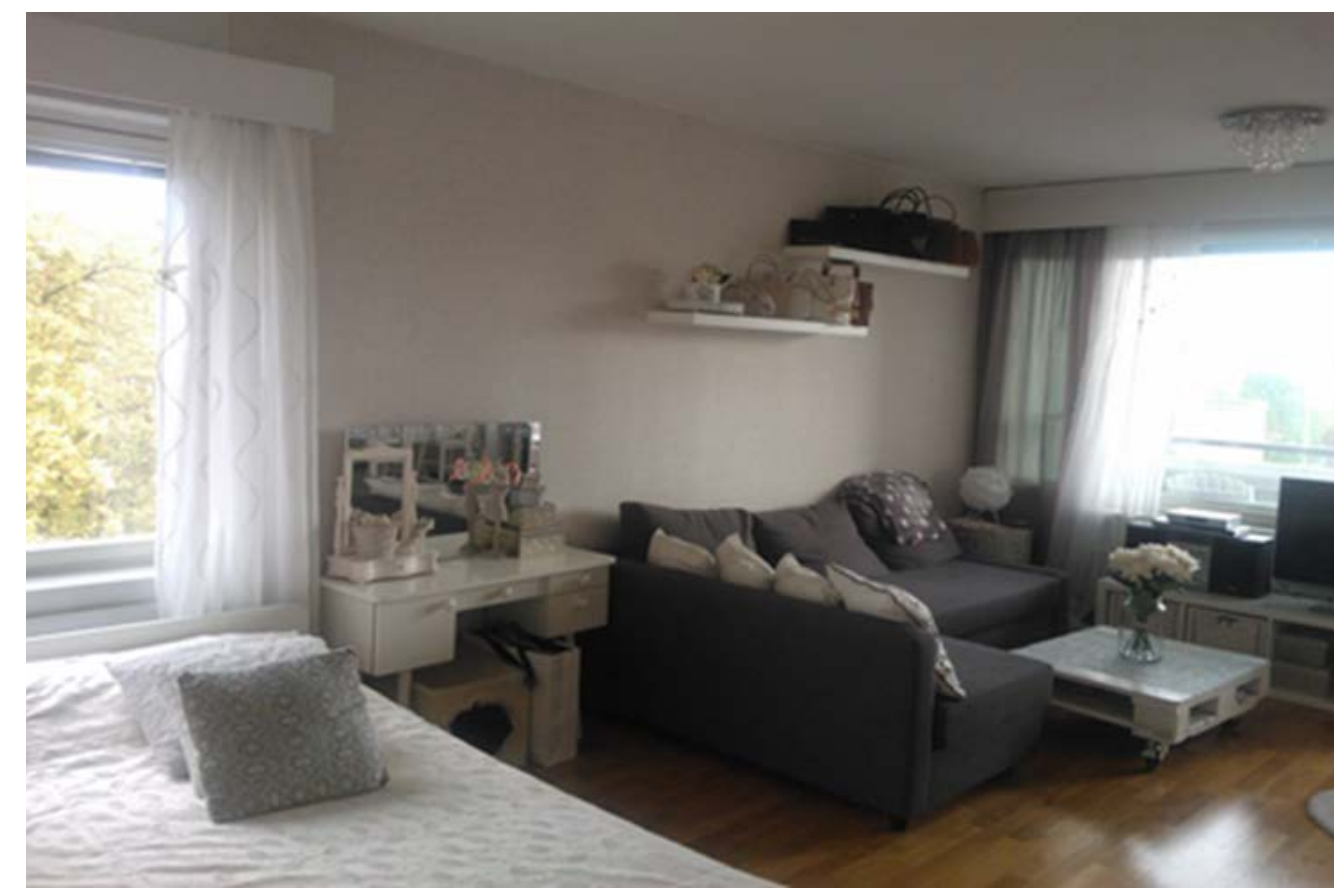

KUVA 2 Osallistujan kuvaama valoisuuden ja avaruuden kokemus

asuntosuunnittelussa on tutkittu viime aikoina paljon (esim. Tregenza \& Wilson, 2011; Hellinga, 2013; Beute, 2014; Paredes, 2016). Asukkaan näkökulma on kuitenkin ollut vähemmän esillä ja tutkimuksessa on huomioitu toistaiseksi vähän aistikokemusten yhteisvaikutuksia tai niiden kytkeytymistä erilaisiin asumisen sosiaalisiin ja kulttuurisiin käytäntöihin ja merkityksiin (ks. esim. Bille, 2014; Kerr ym., 2018).

Asumisen tarjoumien moniaistisella, ruumiillisella ulottuvuudella on selkeästi merkittävä rooli, kun luodaan viihtyisiä asuintiloja, -rakennuksia ja -ympäristöjä. Aihetta voi suunnittelun näkökulmasta lähestyä ainakin huomioimalla rakennusten ja muiden rakenteiden keskinäinen jäsentely ja suuntaus sekä rakennetun ja luonnonympäristön yhteys eri mittakaavoissa. Ne ovat olennaisia kaikkien asumisen aistikokemusten kannalta. Asuinrakennuksen sijainti ja avautuminen tulisi aina huomioida suhteessa päivänkiertoon ja voimakkaisiin äänilähteisiin. Melun saapumista rakennukseen voivat estää harkitusti äänilähteen ja rakennuksen välille sijoitetut maastonmuodot, rakennukset tai muut rakenteet. Toisaalta edellä mainittujen hankala sijainti suhteessa asuntoon voi huonontaa valo-olosuhteita. Myös valoa tai ääntä, joka saapuu ympäristöstä, muista asunnoista tai asunnon sisältä, voidaan rajata paitsi teknisillä materiaali- ja rakenneratkaisuilla myös rakennuksen ja ulkotilan keskinäisen suhteen tai rakennuksen sisätilojen jäsentelyllä. Vaikka näiden kysymysten ratkaisun 
pitäisi olla ilmeinen osa asuntosuunnittelua, uusissakin asuntokohteissa on tilanteita, jossa asunnon tilarakenteen jäsentely tai suuntaus estää optimaaliset valo-olosuhteet (Saarimaa \& Pelsmakers, 2020).

Suunnitteluratkaisut, jotka liittyvät asumisen aistikokemuksiin, liittyvät usein myös tilojen joustavuuteen. Aistien kokemisen vahvuus vaihtelee yksilökohtaisesti. Esimerkiksi ympäristöstä tai asunnon toisista tiloista asuintilaan saapuva ääni tai haju voi olla yleisesti epämiellyttävää, mutta aistiherkälle liikaa. Osa arvostaa asunnoissa avointa mallia, jossa yhteydet ulos ympäristöön, mutta myös asunnon sisäiset äänet ja esimerkiksi ruuanlaiton tuoksut ulottuvat rajoittamatta läpi tilakokonaisuuden, kun taas osalle rajatumpi ja huoneyksiköihin perustuva asunnon malli on sopivampi (Finlay ym., 2012).

Tulosten mukaan asukkaiden myönteiset aistikokemukset liittyivät usein luontoon, joka parhaassa tapauksessa jatkuu kokemuksellisesti ulkoa sisätiloihin - mitä käsitellään seuraavassa jaksossa. Luonnonvalon, kasvillisuuden ja luonnon äänien hyödyntäminen asuntosuunnittelussa näyttäytyy tärkeänä aistikokemusten kannalta. Ikkuna-aukkojen määrällä, koolla, jäsennyksillä ja suuntauksilla voidaan vaikuttaa asuntojen luonnonvalo-olosuhteisiin sekä mahdollistaa jokapäiväinen luonnon aistinta ja seuraaminen. Luonnon ja asumisen kytkeytymisen huomioiminen alkaa jo kaavasuunnittelusta: jos ulkotila rakennusmassojen välissä jää liian pieneksi, aistikokemuksellisesti tärkeät luonnonelementit eivät mahdu avoimina pidettävien pelastusteiden ja tarvittavien pihatoimintojen oheen. Yksityiskohtaisessa asuntosuunnittelussa luontoyhteyttä voidaan edelleen korostaa - tai hukata yhdyskuntasuunnittelussa luotu potentiaali.

\section{Sisä-ja ulkotilojen jatkumot}

Asukkaiden kokemuksia ja arvostuksia on tarkasteltu pihojen osalta suhteellisen paljon (esim. Bhatti ym., 2008; Coolen \& Meesters, 2012b; Hasu, 2014). Laaja kirjo erilaisia sisä- ja ulkotilojen limittymiä sen sijaan ansaitsisi tulostemme perusteella enemmän huomiota (ks. myös Pirinen, 2014, s. 234). Osallistujat keskustelivat paljon sisä- ja ulkotilojen välitilojen sekä niitä yhdistävien jatkumoiden tarjoumista, asumisen puolijulkisista ja puoliyksityisistä tiloista1 ${ }^{1}$. Ikkunanäkymiä käsiteltiin jo asunnon tunnelman ja aistikokemusten näkökulmasta. Ne tuottavat myös kokemuksen asunnon suhteesta ympäristöönsä. Sopiva ikkunanäkymä voi tuottaa luonnonläheisyyden tarjouman, joka on läsnä päivittäisten rutiinien

1 Puolijulkisilla ja puoliyksityisillä tiloilla viitataan tässä tiloihin, jotka sijoittuvat kaikille avoimen julkisen tilan (esimerkiksi katu tai puisto) ja yksityisen tilan (esimerkiksi asunto) välimaastoon. Puolijulkisilla viitataan tiloihin, joita hallinnoivat tietyn korttelin asukkaat (esimerkiksi taloyhtiön pihatilat), kun taas puoliyksityisillä viitataan puolijulkisen ja yksityisen tilan välisiin osiin ja rajapintoihin, joita hallinnoi asukas tai pienempi joukko asukkaita. Ulkopuolinen tarvitsee lupaa näiden tilojen (esimerkiksi asunnon kuistin tai parvekkeen) käyttöön. (ks. Robinson, 2004, s. 175). 
taustana. "Luonto tulee sisään", kuten eräs osallistuja kuvasi. Luonnonläheisyyden minimivaatimuksen saatetaan kokea täyttyvän, jos ikkunasta näkyy puu, jota asukas voi seurata eri vuodenaikoina. Kaivattiin kokemuksia siitä, että on "vihreää ja valoisaa", "ilmaa" tai "happea". Tyytyväisyyttä saattoivat lisätä pienetkin asiat, kuten makuualkovin pieni ikkuna, jonka kautta luonto on läsnä näkymänä ja valona. Keittiön pöydän äärestä näkyvä juuri leikattu vihreä ruoho antoi eräälle haastateltavalle energiaa - tärkeiden kokemusten kuvaukset ja osallistujien valokuvat kytkeytyivät usein tällaisiin hetkiin. Eräs tesomalainen rivitaloasuja kuvaa valokuvansa (kuva 3) avulla, kuinka tilallinen jatkumo sisältä ulos synnyttää hänelle tarjoumia luonnosta nauttimiseen arkisten askareiden keskellä:

Tässä, suoraan keittiöstä on sitten tämmöselle lasiverannalle näkymä, ja siitä sitten ulos ja siellä taitaa takana olla vielä linnunpönttöjä. Eli erilaisia tiloja, mua kiinnostaa se. [T]ää on semmonen näkymä, jossa tulee oltua siis päivittäin. Kun laittaa ruokaa tai (...) niin tää on se näkymä, mistä mä katselen ulos. Tässä toi meiän veranta on vähän niin kun kasvihuone, siinä on lasikatto myös. Nää yrtit jotka on tässä edessä kuvaa myös mun kiinnostustani että mä kasvatan taimia, keväällä tuolla verannan ikkunalla, ja sitten siirrän ne tuonne ulos, kukkapenkkiin. Sitten mä tykkään, ruokkia lintuja, siin on, kaks lintulautaa. Meillä on paljon lintuja ja orava käy siinä, eilen muun muas tikka viihty siinä hyvin meidän takapihalla. Luonto on hyvin merkittävä.

Aineistossamme monet asumisviihtyvyyden kannalta myönteiset valokuvat esittivät asumisen ulkotiloja, kuten parvekkeita, terasseja, patioita, pihoja ja puutarhoja tai yhteispihoja, jotka mahdollistivat monenlaisia tarjoumia. Parvekkeet ja terassit olivat asunnoissa toiminnallisesti monikäyttöistä lisätilaa, sisätilan jatkeita, erityisesti kesäaikaan. Ne tarjosivat tilaa kukkien ja yrttien kasvattamiselle, askartelulle, pienille korjaustöille ja nikkaroinnille, pyykinkuivaukselle, seurustelulle, vilvoittelulle saunan jälkeen, ja jopa nukkumiselle kesäaikaan. Pihat näyttäytyivät sekä erilaisten tekemisten että asumisen tunnelman kannalta tärkeinä paikkoina. Ne tarjosivat mahdollisuuksia ulkona puuhailuun, "kuoputtamiseen", lintujen ruokkimiseen ja luontoyhteyden kokemuksiin. Jo pelkkä näkymä keittiöstä omaan pihaan saatettiin kokea tunnelman kannalta tärkeänä: "se on samalla meidän mökki, vaikkei kukaan käytä tuota pihaa oikeasti”.

Keskustelussa nousivat tärkeinä esiin myös taloyhtiöiden yhteispihat. Erilaiset kontekstit ja korttelirakenteet Tesomalla ja Turussa sekä asukkaiden 


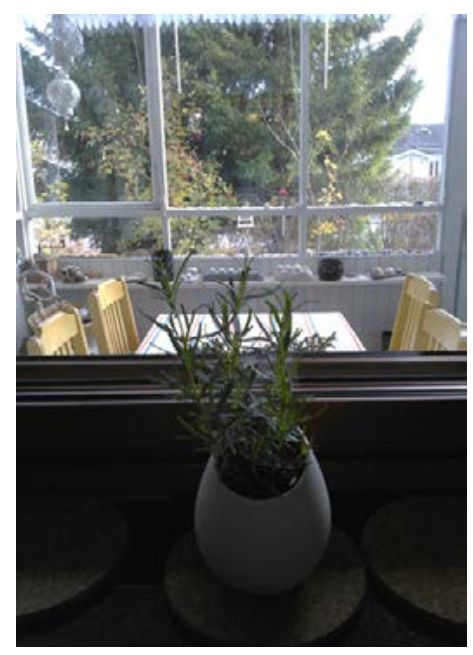

KUVA 3

Osallistujan kuvaama sisä- ja ulkotilojen välinen jatkumo ja koettu luontoyhteys

erilaiset elämänvaiheet tuottivat myös selvästi erilaista pihojen käyttöä. Pihapiireistä oli voinut muodostua sosiaalisia tapahtumapaikkoja, joihin liittyi tavaroiden lainailua ja naapuriapua, mutta isot pihat ja niihin kuuluvien tilojen yksityisyyden ja julkisuuden vaihettuminen sallivat myös sosiaalisen etäisyyden naapureihin. Suoraa näköyhteyttä naapureihin usein vieroksuttiin. Rivitaloasujilla ja Turun puutaloyhtiöissä käytössä olivat sekä oma yksityinen piha että taloyhtiön yhteinen piha. Ne mahdollistivat valinnan yksityisyyden ja sosiaalisuuden välillä pihalla oleilussa. Yhteisessä käytössä oleva puolijulkinen tila mahdollisti luontevan vuorovaikutuksen naapureiden kesken. Mikäli käytössä on lisäksi oma piha, terassi, patio tai parveke, voidaan valita missä määrin kanssakäymiseen osallistutaan. Turussa keskeisinä yhdessäolon tapoina mainittiin mm. naapurien kanssa rakennettu pihasauna ja -paviljonki, kylpypalju, yhteisessä pihapiirissä syöminen, taimien kasvattaminen ja yhteiset juhlat naapurien kanssa.

Asukkaiden erot ja tarpeet erilaisissa elämänvaiheissa ja -tyyleissä korostuivat ja toteutuivat vaihtelevasti erilaisissa fyysisissä ympäristöissä. Lapsiperhevaiheessa pihojen käyttö oli tyypillisesti aktiivisimmillaan, ja oman pihan toimintojen jatkaminen yhteisille ja puolijulkisille piha-alueille koettiin tärkeäksi. Esimerkiksi Tesomalla yhteiskäyttöön hankitun trampoliinin myötä myös yhteinen piha-alue koettiin omaksi. Yksityisten pihojen tarjoumien yhdisteleminen ja jaetut käytöt osoittautuivat tesomalaisten lapsiperheiden asuinympäristöissä tavallisiksi; lapset kulkivat vuorotellen leikkimässä toinen toistensa pihoilla ja kokosivat leikkeihin tarjoumayhdistelmiä pitkin matkaa. Lasten muutettua kotoa leikit, pelaaminen ja yhdessäolo pihoilla jäivät vähemmälle, mikä näkyi kerrostaloyhtiöiden hiljaisissa pihapiireissä. 
Ikäihmisten ryhmissä kerrostalojen yhteispihojen toimintoina painottuivat yhdessäolo ja sosiaaliset kohtaamiset, yksinäisyyden torjunta ja ympäristön elämän seurailu. Joillekin ikäihmisille aktiivinen puuhaaminen pihassa oli tärkeää: esimerkiksi kodin toimintojen ja puuhien siirtäminen ulos, "kaikenmaailman perkaaminen" ja säilöminen tai pihalla "kuoputtaminen ja tekeminen". Tällaiset yhteispihojen tarjoumat ovat varteenotettava näkökohta, kun ajatellaan muista talotyypeistä kerrostaloon muuttavia ikääntyviä asukkaita. Tesomalainen osallistuja kuvaa kerrostalon pihapiirin elämää:

Vesi kielelle teille tulee, niin viime keskiviikkona ystäväni Matin kanssa savustettiin siinä oli muutamia muitakin, lipomassa kieliään ja jotain juomaakin ne tarjoili vähän siinä ja, noin 10 kiloo me savustettiin. Ihan itte pyydetty.

Opiskelijoiden fokusryhmissä pihojen aktiivinen käyttö ei muiden ryhmien tapaan ollut juuri esillä. Poikkeuksen muodosti Turussa Port Arthurin kaupunginosassa sijaitsevan puutaloyhtiön pihapiiri, jossa oli paljon erimuotoista sosiaalista kanssakäymistä. Opiskelijoiden näkökulmasta tärkeiksi koettiin lähinnä käytännölliset seikat kuten polkupyörän säilyttäminen ja piha-alueiden riittävä valaistus pimeän aikaan.

Yhteispihan ottamisessa asukkaiden käyttöön todettiin kuluvan oman aikansa, samoin kuin että asukkaiden vaihtuessa sen käyttöön voi tulla katkoksia. Samalla pihan ympäristö muuttuu, kasvillisuus kasvaa ja rakennettu ympäristö ikääntyy. Joskus aiemmin hyvin palvellut piha ei enää vastaa nykyisten asukkaiden tarpeisiin. Muun muassa näistä syistä keskusteluissa nousi usein esiin omaehtoisen tekemisen tai itse muokkaamisen toive yhteisillä piha-alueilla.

Sisä- ja ulkotilojen jatkumoista fokusryhmissä käyty keskustelu havainnollistaa paitsi tarjoumien arvostuksiin liittyviä ryhmäkohtaisia eroja, myös tarjoumien yksilöllisyyttä. Esimerkiksi pihoihin liittyvät tarjoumat voivat olla hyvinkin spesifejä, kuten keittiön ikkunasta näkyvä vastaleikattu ruoho, turkulaisen yhteispihan mahdollisuus paljussa loikoiluun tai kalojen savustusmahdollisuus tesomalaisella kerrostalopihalla. Asumisen kulttuuri, yksilön elämänhistoria ja mieltymykset vaikuttavat siihen, millaiset tarjoumat näyttäytyvät oleellisina.

Mä olen syntynyt tietysti maalla, mä oon aina sanonu et kanankakkaa varpaanvälissä niin jotenkin mun mielestä mun asunnossa, mun mielest asunnossa kuuluu olla myös ulkoseinät ja piha. Elikkä et saa jalat ovesta ulos. 
Sisä- ja ulkotilojen jatkumot suunnittelun näkökulmasta

Tuloksemme alleviivaavat, että asuntoa tulee lähestyä suunnittelussa aina osana laajempaa ympäristöä. Tilojen jatkumoiden ja limittymisen merkitys voidaan huomioida tavoittelemalla julkisuusasteiltaan monipuolisia ja huokoisessa suhteessa toisiinsa olevia ulkotilojen sarjoja sekä yhdistämällä tietoisesti asuntojen sisä- ja ulkotiloja.

Laadukkaat ulkotilat liittyvät niin sanottuun asunnon "ulkoiseen käytettävyyteen", jonka on nähty tuovan lisäarvoa asumiseen (Lehtonen, 2010), minkä myös tuloksemme pihojen ja yhteispihojen sosiaalisesta ja toiminnallisesta merkittävyydestä vahvistivat. Asumisen reviiri hahmottuu asuntoa laajempana tilojen ja toimintojen kudelmana, ja asumisen tarjoumia lisää se, että yksityisen asunnon ulkopuolisia tiloja voi käyttää monipuolisesti. Yksityisen ja julkisen tilan liukuminen toistensa lomaan huokoisten mutta selkeästi jäsenneltyjen puoliyksityisten, puolijulkisten ja -julkisten tilojen kautta edesauttaa sitä, että asukkaat ottavat asunnon ulkoisia tiloja käyttöönsä (van Dorst, 2005).

Sisä- ja ulkotilojen monipuolinen yhdisteleminen on kiinnostava haaste uudisrakennusten suunnittelulle ja urbaanien talotyyppien kehittelylle. Vaikka tuore tutkimus käsittelee asumisen ympäristöjä kokonaisvaltaisesti, sisä- ja ulkotilan rajaa häivyttäen (esim. Hasu, 2014; Maununaho, 2018), ovat sisä- ja ulkotilojen väliset jatkumot niukasti tarkasteltu aihealue asuntosuunnittelun ohjeistuksissa. Tulokset alleviivaavat sen huomioimista, miten asukkaat liikkuvat sisään ja ulos asunnon sisäosan ja asuntokohtaisen ulkotilan välillä ja miten he voivat oleskella ulkotiloihin avautuvien näkymien läheisyydessä. Lisäksi tuloksista välittyy tarve huomioida suunnittelussa se, miten asunnon ulkotila sallisi yksilölliset ja vaihtelevat käytöt. Merkittävässä roolissa eivät siis ole vain tilan muoto ja laajuus, vaan myös rajaavien pintojen materiaalit ja asuntokohtaisten ulkotilojen viereiset alueet sekä niiden julkisuusasteet. Avainasemaan nousevat tässäkin asukaslähtöisyys ja valinnan mahdollisuudet: sisä- ja ulkotilan kytkös tulisi tehdä mahdolliseksi, mutta sallia myös tilan yksilölliset käytöt.

\section{Tilojen joustaminen erilaisiin tarpeisiin}

Fokusryhmäkeskusteluissa kävi ilmi, että koti merkityksineen on jatkuva prosessi, jossa sitä muovataan ja pidetään yllä. Aineistossa on lukuisia esimerkkejä siitä, kuinka asukas sopeutuu tilaan tai sopeuttaa tarjolla olevia tiloja omiin tarpeisiinsa. Esimerkiksi saunatiloja käytetään pyykkihuoltoon tai varastotiloina (vrt. aiemmin käsitelty aputilojen tarve).

Monet tilat näyttäytyivät osallistujille aidosti monikäyttöisinä. Esimerkiksi asuntokohtaiset ulkotilat taipuivat moneen. Myös keittiö oli useassa asunnossa tilana monitoimintoinen. Sen mahdollinen yhdistyminen laajempaan 
olohuoneesta tai ruokailuhuoneesta koostuvaan tilakokonaisuuteen laajensi edelleen koettuja toiminnallisia mahdollisuuksia. Tesomalla suhteellisen suurten kerrostaloasuntojen hyviä pohjia kiitettiin: huoneet olivat riittävän suuria, jotta niiden käyttötarkoituksia oli mahdollista muunnella. Esimerkiksi asukkaat, jotka olivat jääneet asumaan samaan asuntoon lasten muutettua pois, kokivat asumisväljyyden ja alueen kerrostaloasuntojen avarat pohjaratkaisut myönteisinä. Vapautunutta tilaa oli otettu käyttöön uusin tavoin, esimerkiksi kotitoimistoksi tai perheen äidin ensimmäiseksi "omaksi huoneeksi". Turun aineistossa puolestaan eräs perhe oli vuokrannut samasta kerrostalosta toisen asunnon, kun tilantarve oli kasvanut eikä lähistöltä ollut löytynyt suurempaa asuntoa. Lasten muutettua pois kotoa palveli vuokrattu huone kotikirjastona ja oli osallistujan lempipaikka kodissa.

Asumistarpeista tai niiden muutoksista keskusteltaessa nousi esiin myös useita pienempiä tai suurempia remontteja, rakentamista tai uusia tilaratkaisuja, jotka toivat asumiseen lisäarvoa ja tekivät asunnosta "enemmän omannäköisen". Suuri osa asukkaista ilmaisikin toiveen muokata asuntoa omien tarpeiden ja mieltymysten mukaiseksi, riippumatta siitä asuivatko he omistusasunnossa vai vuokralla. Tekeminen itse ja mahdollisuus vaikuttaa asuntoihin voivat olla myös arvo sinänsä. Alla olevassa kuvauksessa remontoimisen mahdollisuus liittyi oman paikan ottamiseen uusperheessä:

No esimerkiks siitä kun tulee siis taloon jossa, mä oon se, uutukainen. Ja henkisel tasol tietenkin että miten mut otetaan vastaan, äitipuolena. Mistä mä saan määrätä. Ja mikä on mun aluetta, mikä on meiän yhteistä aluetta. (..) [naurahtaa] Älvsby niin, se on semmonen muotti et sit se, on bulkkimyytynä ja pitäs sopii kaikkeen ja, kätevä käsistään kun mies on et pystytään muuttamaan myös, sitä olemassa olevaa taloa. Ja mahdollisuuksien mukaan jopa, tontin antaen myötä ja rakennuslupien niin vähän rakentaa lisää.

Pirinen (2014) on todennut asuntojen muuttuvan elinkaarensa aikana asukkaiden yksilöllisten mieltymysten ja päämäärien mukana. Näin ollen asunto ei ole koskaan "valmis" ja täydellisesti asukkaan mieltymystä vastaava, vaan "jokapäiväinen elämä tuo suhteeseen satunnaisuutta, mikä estää täydellisen yhteensopivuuden saavuttamista asumisessa" (Pirinen, 2014, s. 13). Silti tiloja voidaan myös suunnitella sopimaan erilaisiin ja muuttuviin tarpeisiin.

\section{Erilaisiin tarpeisiin joustavat tilat suunnittelun näkökulmasta}

Ajatus ihmisen ja ympäristön vuorovaikutteisuudesta ja asumisen prosessuaalisuudesta onkin myös osa monia arkkitehtuurin alan teorioita (esim. Habraken, 
1972; 1998). Habraken (1998) pitää vuorovaikutteista uudelleenmäärittämistä merkittävänä prosessina rakennetun ympäristön kestävyyden näkökulmasta. Se voi tapahtua monin eri tavoin ja monissa eri mittakaavoissa, kuten asuintilan, -rakennuksen tai -korttelin monikäyttöisyyden tai eri asteisen ja eri aikasykleillä toteutuvan tilallisen mukautumiskyvyn keinoin. Monikäyttöisyys korostaa sitä, miten tilajärjestelmä sellaisenaan mahdollistaa vaihtelevia käyttöjä, kun taas mukautumiskyky viittaa tilojen fyysisten muutosten mahdollisuuksiin. (Schneider \& Till, 2007; Schmidt \& Austin, 2016).

Monikäyttöisyyden tarve nousi tuloksissa esiin niin asunnon kuin asuntokohtaisten ja jaettujen ulkotilojen kohdalla. Aidosti monikäyttöinen asuinhuone on kuitenkin melko kookas, ihannetapauksessa esimerkiksi 3,6 metriä leveä ja 4,O metriä syvä (schneider \& Till, 2007, s. 186, ks. myös Leupen, 2006). Monikäyttöinen asunto on taas useiden monikäyttöhuoneiden ja keskeisen hallin yhdistelmä (Leupen, 2006). Asuntojen hintojen ollessa korkeat varsinkin kasvukeskuksissa, on ylimääräisten huoneneliöiden varaaminen useisiin huonetiloihin asukkaalle kallis vaihtoehto. Asukkaiden kokemuksista kävi ilmi, että myös pienemmät ja tarvittaessa suljettavat tilat saattoivat tarjota tarvittavaa joustoa, esimerkiksi hiljaisen työtilan. Suunnittelussa olisikin huomioitava monipuolinen kalustettavuus tilojen koosta huolimatta sekä asukkaiden mahdollisuus vaikuttaa huone- ja tilajakoihin sekä -kokoihin.

Aiheesta on runsaasti kansainvälistä tutkimuskirjallisuutta, ja Suomessakin asuntojen joustavuutta on käsitelty rakennusesimerkkien valossa ja kategorisoiden kahdessa väitöskirjassa (Krokfors, 2017; Tarpio, 2015). Tutkimuksemme keskittyy näistä poiketen asukkaiden näkökulmaan, jossa korostuivat erityisesti sellaisenaan käytettävissä olevat joustavuuden muodot, kuten monikäyttöisyys ja asumisen laajeneminen sisätilasta ulos.

Toisaalta nousi esiin myös tilallinen mukautumiskyky, mikä tukee myös muiden houkuttelevan asumisen ainesten toteuttamista suunnittelussa. Esimerkiksi pohjaratkaisultaan mukautuvissa asunnoissa asukas voi valita erilaisia, yksilöllisiin tarpeisiin sopivia, toissijaisten tilojen kattauksia. Myös suunnitteluratkaisut, jotka vaikuttavat asumisen aistikokemuksiin ja niiden hallintaan, liittyvät tilalliseen mukautumiskykyyn. Suunnittelun näkökulmasta joustavuus näyttäytyi siis edellä kuvattujen teemojen läpileikkaavana piirteenä.

\section{Johtopäätökset}

Tarkastelimme artikkelissa sitä, mitkä tai minkälaiset tarjoumat tekevät asumisen tiloista asukkaille viihtyisiä ja houkuttelevia. Pyrimme myös reflektoimaan tuloksia siitä näkökulmasta, että ne palvelisivat mahdollisimman hyvin asukaskeskeisen suunnittelun tiedontarpeita. Toisin sanoen, rakentamaan 
sillan asukkaiden eletyn arjen ja tarjoumien todellisuudesta yleispäteviin suunnitteluperiaatteisiin.

Jäljitimme asukkaille merkityksellisiä tarjoumia osallistavaa valokuvamenetelmää hyödyntävin fokusryhmähaastatteluin. Metodologisesti oleellista oli, että jäsennykset lähtivät asukkaista itsestään, heidän kokemuksistaan asuinympäristöstä ja eletystä tilasta, sen sijaan että olisimme esittäneet heille valmiita kysymyksiä tai vastausvaihtoehtoja. Apuna toimivat asukkaiden ottamat valokuvat, joista käyty keskustelu helpotti asumisen koetun maailman yhdistämistä fyysiseen ja geometriseen maailmaan sekä sen suunnitteluvaihtoehtoihin.

Fokusryhmät pystyivät identifioimaan asumisensa kannalta merkityksellisiä seikkoja, jotka aineiston analyysissä yhdistimme tarjoumien kategorioiksi. Ne ovat artikkelin nimen mukaiset houkuttelevan asumisen ainekset: eri elämäntilanteissa toimivat asunnon toissijaiset tilat, miellyttävät aistikokemukset, toiminnallisesti ja kokemuksellisesti monipuoliset sisä- ja ulkotilojen väliset jatkumot sekä tilaratkaisujen joustavuus. Analyysissä kategorioiden sisällä näyttäytyi myös tarjoumien yksilöllisyys, moninaisuus ja monimuotoisuus, mutta yleistävä kategorisointi auttoi suodattamaan niistä suunnittelulle hyödyllistä tietoa.

Kiinnostavaa on myös se, mitä menetelmä ei tavoittanut. Asukkaiden kuvissa ei näkynyt lainkaan toisia ihmisiä, ja sosiaalisten tilanteiden kuvailut olivat aineistossa harvinaisia. Myöskään asunnon yksityisimpiä tiloja, esimerkiksi makuuhuoneita, ei juuri kuvattu. Syyt voivat olla joko käytännöllisiä tai liittyä siihen, mitä osallistujat halusivat näyttää tutkijoille ja muille fokusryhmäläisille, mitä taas piilottaa katseilta (Loopmans ym., 2012; Rose, 2016, s. 324). Valokuva-aineisto saattaa kallistua kohti visuaalisesti helposti esitettäviä seikkoja (da Silva Vieira \& Antunes, 2014). Osallistujat keskustelivat suhteellisen vähän esimerkiksi asuntojen pohjista ja eri tilojen välisistä suhteista, minkä yksi syy voi olla niiden hankala tallentaminen yksittäiseen valokuvaan. Tulos eroaa Pirisen (2014, s. 234) tietynlaisiin asuntotyyppeihin kohdistuvasta tutkimuksesta, jossa valokuvia käytettiin muiden menetelmien rinnalla, ja jossa myös asuntojen koko ja tilojen väliset suhteet nousivat esiin. Toisaalta tutkimuksemme osallistujat kuvasivat usein esimerkiksi moniaistisia asumisen kokemuksia, kuten tuoksuja ja ääniä, käyttäen valokuvausta luovasti myös näiden ei-visuaalisten kokemusten esittämiseen. Laadullisesta aineistosta ei myöskään voida tehdä määrällisiä yleistyksiä. Tulosten yleistettävyyttä lisää kuitenkin se, että aineistossa kuultiin heterogeenistä ja jopa suhteellisen laajaa asukasjoukkoa, joka keskusteli asumisestaan fokusryhmittäin.

Tarjoumat syntyvät monitahoisissa vuorovaikutuksissa ympäristön ja kokijan välillä eikä tarjoumia siis voi suoraan suunnitella. Suunnittelulla voidaan sen sijaan vahvistaa houkuttelevan asumisen aineksia eli yleisempiä 
tarjoumien kategorioita. Tarjoumia koskeva laadullinen tutkimus osoittautuikin tutkimuksessamme toimivaksi tavaksi tuottaa suunnitteluun pohjatietoa asumisen topologiasta eli kokemuksellisuudesta topografisen ja geometrisen tiedon rinnalle (vrt. Nethercote \& Horne, 2016). Teollisen asuntotuotannon kritiikki osoittaa, että kaivataan selkeitä periaatteita, joilla hankkeiden laatua voidaan arvioida myös asukkaan näkökulmasta.

Tulosten valossa asuntosuunnittelussa tulisi huomioida paremmin tilojen kokemuksellisuus ja asukastarpeiden moninaisuus tilan käytettävyyden ja käytännöllisyyden ohella. Tämä on tärkeää myös asunnon toissijaisissa tiloissa sekä asuntokohtaisissa ulkotiloissa. Asumisen aistikokemuksiin vaikuttavat rakennusten jäsentelyn ja suuntausten valinnat eri mittakaavoissa sekä luonnon ja rakennetun ympäristön että sisä- ja ulkotilojen monipuolinen yhdisteleminen. Nämä seikat luovat kiinnostavia haasteita paitsi urbaanien talotyyppien kehittelyyn myös kaupunkisuunnitteluun. Sisä- ja ulkotilojen tärkeäksi koettua jatkumoa tukevat selkeästi merkityt puoliyksityiset ja puolijulkiset tilat, jotka rakentavat tilasarjan yksityisen ja julkisen välille. Asuntosuunnittelun näkökulmasta tärkein viesti onkin, että tilojen elinkaaren aikana muunneltavissa oleva käyttö tulee huomioida jo suunnitteluvaiheessa. Eri asteinen tilallinen joustavuus on houkuttelevan asumisen aineksia läpileikkaava piirre, jonka tulisi määrittää asuntojen suunnittelua.

\section{KIRJALLISUUS}

Beute. F. (2014). Powered by nature: the psychological benefits of natural views and daylight. Doctoral dissertation. Eindhoven: Eindhoven University of Technology. https://doi.org/10.610o/IR780722

Bhatti, M., Church, A., Claremont, A. \& Stenner, P. (2008). I love being in the garden: Enchanting encounters in everyday life. Social \& Cultural Geography, 10(1), 61-76. https://doi.org/10.1080/14649360802553202

Bille, M. (2015). Lighting up cosy atmospheres in Denmark. Emotion, Space and Society,15, 56-63. https://doi. org/10.1016/j.emospa.2013.12.008.

Broberg, A.; Kyttä, M. \& Fagerholm, N. (2013). Child-friendly urban structures: Bullerby revisited. Journal of Environmental Psychology, 35, 110-120. https://doi.org/10.1016/j.jenvp.2013.06.001

Clapham, D. (2011). The Embodied Use of the Material Home: an Affordance Approach, Housing, Theory and Society, 28(4), 360-376. https://doi.org/10.1080/14036096.2011.564444

Coolen, H. (2015). Affordance based housing preferences. Open House International, 40(1), 74-80.

Coolen, H. \& Meesters, J. (2012a). Editorial special issue: house, home and dwelling. J Hous and the Built Environ, 27, 1-10. https://doi.org/10.1007/s109o1-011-9247-4

Coolen, H. \& Meesters, J. (2012b) Private and public green spaces: meaningful but different settings. J Hous and the Built Environ, 27, 49-67. https://doi.org/10.1007/s1ogo1-011-9246-5.

da Silva Vieira, R. \& Antunes, P. (2014). Using photo-surveys to inform participatory urban planning processes: Lessons from practice. Land Use Policy, 38, 497-508. https://doi.org/10.1016/j. landusepol.2013.12.012

Finlay, S.; Pereira, I.; Fryer-Smith, E.; Charlton, A. \& Roberts-Hughes, R. (2012). The way we live now: what people need and expect from their homes. Research report for the Royal Institute of British Architects, Home wise, RIBA. [viitattu: 18.5.2020] https://www.ipsos.com/sites/default/files/publication/1970-01/ sri-riba-the-way-we-live-now-may-2012.pdf 
Fozdar, F. \& Hartley, L. (2014). Housing and the Creation of Home for Refugees in Western Australia. Housing, Theory and Society, 31(2), 148-173. https://doi.org/10.1080/14036096.2013.830985

Gibler M., K. \& Tyvimaa, T. (2014). The Potential for Consumer Segmentation in the Finnish Housing Market. Journal of Consumer Affairs, 48(2), 351-379. https://doi.org/10.1111/joca.12037.

Gibson, J. (1979) The Ecological Approach to Visual Perception. Boston: Houghton Mifflin.

Hasu, E. (2014). Governing domestic space: Townhouse related living, gardens and the home- making process in Finland, Teoksessa Proceedings of the 6th Annual Architectural Research Symposium in Finland 2014: Designing and planning the built environment for human well-being. Oulu, Finland, 86-103.

Hasu, E. (2017). Asumisen valinnat ja päätöksenteko paljastettuina: "Mitä kaikkea me ei tajuttukaan kun tähän muutettiin ja mökistä luovuttiin”. Väitöskirja. Doctoral Dissertations 43/2017. Espoo: Aalto yliopisto.

Harper, D. (2002). Talking about pictures: A case for photo elicitation. Visual Studies, 17(1), 13-26. https://doi. org/10.1080/14725860220137345

Helander, H. (2020). Korjausliike kohti hyvinvointia. Arkkitehtiliitto Safan blogi [julkaistu: 23.1.2020] https://www.safa.fi/blogi/korjausliike-kohti-hyvinvointia/

Hellinga, H. I. (2013). Daylight and View: The Influence of Windows on the Visual Quality of Indoor Spaces. Doctoral dissertation. Delft: Delft University of Technology.

Heft, H. \& Kyttä, M. (2006). A psychologically meaningful description of environments requires a relational approach. Housing, Theory and Society, 23(4), 210-213. https://doi.org/10.1080/14036090600909550

Huttunen, H.; Hasu, E.; Hirvonen, J.; Tervo, A. \& Ullrich T. (2015). Uusi suomalainen unelmakoti? Asukasnäkökulma townhouse-asumiseen.

Aalto-yliopiston julkaisusarja TAIDE + MUOTOILU + ARKKITEHTUURI 6/2015. Helsinki: Aalto-yliopisto, Taiteiden ja suunnittelun korkeakoulu, Arkkitehtuurin laitos

Ilmonen, M. (2007). Vetovoimainen kerrostalo. Teoksessa Kerrostalojen kehittäminen, talotyyppiselvitys. Helsingin kaupunkisuunnitteluviraston julkaisuja 2007:10. Helsinki: Kaupunkisuunnitteluvirasto.

Jacobs, J., M. \& Merriman, P. (2011). Practising architectures. Social \& Cultural Geography, 12(3), 211-222. https://doi.org/10.1080/14649365.2011.565884

Juntto, A. (2008). Asumisen muutos ja tulevaisuus. Rakennetarkastelu: erilaistuva asuminen. Osaprojekti 1, Helsinki: Ympäristöministeriö.

Kahila-Tani, M. \& Kyttä, M. (2017). Laajapohjaisella vuorovaikutuksella kohti vaikuttavaa osallistumista. Teoksessa: Bäcklund, P.; Häkli, J. \& Schulman, H. (toim.) Kansalaiset kaupunkia kehittämässä. Tampere: Tampereen yliopistopaino, s. 137-16o.

Kellert, S. R. (2005). Building for Life: Designing and Understanding the Human-nature Connection. Washington, DC: Island Press.

Kellert, S. \& Calabrese, E. (2015). The Practice of Biophilic Design. http://www.bullfrogfilms.com/guides/ biodguide.pdf

Kerr, S.; Gibson,C. \& Klocker, N. (2108). Parenting and neighbouring in the consolidating city: The emotional geographies of sound in apartments. Emotion, Space and Society,26, 1-8. https://doi.org/10.1016/j. emospa.2017.11.002.

King, P. (2017). Living Alone, Living Together : Two Essays on the Use of Housing: Vol. First edition. Melbourne: Emerald Publishing Limited.

Kohon, J. \& Carder, P. (2014). Exploring identity and aging: Auto-photography and narratives of low income older adults. Journal of Aging Studies, 30, 47-55. https://doi.org/10.1016/j.jaging.2014.02.006.

Krokfors, K. (2017). Time for space: typologically flexible and resilient buildings and the emergence of the creative dweller. Väitöskirja. Espoo: Aalto yliopisto.

Kuoppa, J.; Nieminen, N.; Ruoppila, S. \& Laine, M. (2019). Elements of desirability: exploring meaningful dwelling features from resident's perspective. Housing Studies. https://doi.org/10.1080/02673037.2019. .1680812

Kyttä, M., Broberg, A., Tzoulas, T. \& Snabb, K. (2013). Towards contextually sensitive urban densification: Location-based softGIS knowledge revealing perceived residential environmental quality. Landscape and Urban Planning, 113, 30-46. https://doi.org/10.1016/j.landurbplan.2013.01.008 
Kyttä, M.; Oliver, M.; Ikeda, E.; Ahmadi, E; Omiya, I. \& Laatikainen, T. (2018) Children as urbanites: mapping the affordances and behavior settings of urban environments for Finnish and Japanese children. Children's Geographies, 16(3), 319-332. https://doi.org/10.1080/14733285.2018.1453923.

Lapintie, K. (2010). Intohimon hämärä kohde - Mitä asukas haluaa? Yhdyskuntasuunnittelu, 48(2), 41-57.

Lehtonen, H. (2010). Kaupunkiasumisen monimuotoisuus, palvelut ja james-konsepti. Teoksessa Norvasuo, M. (toim.) Asutaan urbaanisti! Laadukkaaseen kaupunkiasumiseen yhteisellä kehittelyllä, Yhdyskuntasuunnittelun tutkimus- ja koulutuskeskuksen julkaisuja B 99. Espoo: Teknillinen korkeakoulu.

Leupen, B. (2006). Polyvalence, a concept for the sustainable dwelling. Nordic Journal of Architectural Research, 19(3), 23-31.

Loopmans, M., Cowell, G. \& Oosterlynck, S. (2012). Photography, public pedagogy and the politics of placemaking in post-industrial areas. Social \& Cultural Geography, 13, 699-718. https://doi.org/10.1080/1464 9365.2012 .723734

Maier, R. A., Fadel, G. \& Battisto, D. (2009). An affordance-based approach to architectural theory, design, and practice." Design Studies, 30, 393-414. https://doi.org/10.1016/j.destud.2009.01.002

Maununaho, K. (2018). Ihmisen näkökulma integroidun asumisen jaetuissa tiloissa. Yhdyskuntasuunnittelu, $56(4) \cdot 28-44$.

McCarthy, L. (2018). (Re)conceptualising the boundaries between home and homelessness: the unheimlich. Housing Studies, 33(6), 960-985. https://doi.org/10.1080/02673037.2017.1408780

Nethercote, M., \& Horne, R. (2016). Ordinary vertical urbanisms: City apartments and the everyday geographies of high-rise families. Environment and Planning A: Economy and Space, 48(8), 1581-1598. https://doi.org/10.1177/o308518X16645104

Nylander, O. (2002). Architecture of the Home. Iso-Britannia: John Wiley \& Sons LTd Publications.

Paredes, C. (2016). Daylighting and Architectural Quality. Aesthetic Perception of Daylit Indoor Environments. Doctoral dissertation. Trondheim: Norwegian University of Science and Technology.

Paterson, M. (2017). Architecture of sensation: Affect, motility and the oculomotor, Body \& Society, 23, 3-35. https://doi.org/10.1177/1357034X16662324

Pirinen, A. (2014). Dwelling as a product. Perspectives on housing, users and the expansion of design. Väitöskirja. Aalto University publication series, 12/2014. Helsinki: Aalto yliopisto.

Robinson, J. (2004). Architecture of Institution \& Home. Architecture as Cultural Medium. Väitöskirja. Delft: Delft University of Technology.

Rose, G. (2016). Visual Methodologies. An Introduction to Researching with Visual Material, 4th ed. London: Sage Publications Ltd.

RT Rakennustieto Oy. (2008). RT 93-10937, Asuntosuunnittelu. Eteinen ja kulkuyhteydet. Saatavilla:https:// kortistot.rakennustieto.fi/kortit/RT\%2093-10937.

RT Rakennustieto Oy. (2009). 93-10945 Asuntosuunnittelu. Säilytys. Saatavilla: https://kortistot. rakennustieto.fi/kortit/RT\%2093-10945

Schmidt III, R. \& Austin S. (2016). Adaptable Architecture: Theory and Practice. London: Routledge.

Schneider, T. \& Till, J. (2007). Flexible Housing. Amsterdam, Boston: Architectural Press.

Soaita, A. M. \& McKee, K. (2020. Researching Home's Tangible and Intangible Materialities by PhotoElicitation. Housing, Theory and Society. DOI: 10.1080/14036096.2020.1738543

Steele, W. \& Keys, C. (2015). Interstitial Space and Everyday Housing Practices, Housing, Theory and Society, 32(1), 112-125. https://doi.org/10.1080/14036og6.2014.938866

Tarpio, J. (2015). Joustavan asunnon tilalliset logiikat: Erilaisiin käyttöihin mukautumiskykyisen asunnon tilallisista lähtökohdista ja suunnitteluperiaatteista. Väitöskirja. Tampere: Tampereen teknillinen yliopisto.

Tervo, A. \& Hirvonen, J. (2019). Solo dwellers and domestic spatial needs in the Helsinki Metropolitan Area, Finland. Housing Studies. DOI: 10.1080/02673037.2019.1652251

Tervo, A. \& Lilius, J. (2017) Urbaanien yksinasujien asuintilatoiveita. Yhdyskuntasuunnittelu, 55(1).

Tregenza, P. \& Wilson, M. (2011). Daylighting: architecture and lighting design. New York: Routledge. ISBN 978-0-419-25700-4

van Dorst, M. (2005). Physical conditions for social interaction in the home environment. Conference 'Doing, thinking, feeling home: the mental geography of residential environments', Delft, 14-15.10.2005. 